\title{
THE EFFECT OF ONLINE SHOP OWNER SATISFACTION ON LOGISTIC SERVICES (COMPARATIVE STUDY OF JNE AND J\&T EXPRESS)
}

\author{
Kinda Rizki Widianti*)1, Eko Ruddy Cahyadi*), and Alim Setiawan*) \\ $\left.{ }^{*}\right)$ Departement of Management, Faculty of Economics and Management, IPB University \\ Jl. Agatis, Campus IPB Dramaga Bogor 16680, Indonesia
}

\begin{abstract}
Business transactions are important with the increasing of online shop in Indonesia. Every year online shops in Indonesia are increasing in accordance with the existing of technology. The impact of logistic companies as online shop partner is always improving their services to facilitate business transactions. This study aims to compare logistic services between JNE and J\&T Express companies based on online shop satisfaction. The satisfaction of some online shops as both customers and working partners with the logistics companies will be important for both companies. The methods used are Importance Performance Analysis (IPA) and T-test with a sample of 150 owners. Purposive sampling is used as the sampling technique and data is collected by distributing questionnaires through online shop media social. From the fifteen attributes, important services according to online shop are responsiveness to damaged goods and lost goods, guarantees for damaged goods and lost goods, the company's mode of communication to its customers, the company's consistency in maintaining goods properly and consistency of delivery time to the consumer. The results of the study show that JNE and J\&T Express have a significant difference, namely the superiority of JNE in maintaining goods properly inappropriate with the price their given. Meanwhile, the JNE and J \& T Express have a significant inconsistency of delivery time.
\end{abstract}

Keywords: importance performance analysis (ipa), customer satisfaction, logistic sevices perfomance, JNE, online shop

\begin{abstract}
Abstrak: Transaksi bisnis adalah suatu hal yang penting dengan meningkatnya online shop di Indonesia. Setiap tahunya online shop di Indonesia semakin meningkat sesuai dengan keberadaan teknologi. Dampaknya perusahaan logistik sebagai mitra kerja online shop selalu memperbaiki layananya untuk memudahkan jalanya transaksi bisnis. Penelitian ini bertujuan untuk membandingkan layanan logistik antara perusahaan JNE dan J\&T Express berdasarkan kepuasan online shop. Kepuasan online shop sebagai pelanggan dan juga mitra kerja dari perusahaan logistik tersebut saat ini sangat besar pengaruhnya bagi kedua perusahaan. Metode yang digunakan dalam penelitian ini adalah Importance Perfomance Analysis (IPA) dan Uji T dengan sampel sebanyak 150 owner dan teknik pengambilan sampel menggunakan purposive sampling. Pengumpulan data dilakukan dengan cara menyebarkan kuisioner melalui media sosial online shop tersebut. Dari lima belas atribut, layanan yang penting menurut online shop adalah cepatnya daya tanggap terhadap barang yang rusak dan hilang, adanya jaminan terhadap barang yang rusak dan hilang, cara komunikasi yang baik terhadap pelanggan, konsistensi dalam menjaga barang dan kecepatan waktu sampai serta kondisi barang sampai ke konsumen. Hasil dari penelitian menunjukan bahwa JNE dan J\&T Express memiliki perbedaan yang signifikan yaitu keunggulan JNE dalam menjaga kondisi barang yang sesuai dengan harga yang diberikan jika dibandingkan dengan J\&T Express. Sedangkan, antara JNE dan J\&T Express memiliki persamaan yang signifikan yaitu pada konsistensi kecepatan waktu sampai.
\end{abstract}

Kata kunci: importance perfomance analysis (ipa), kepuasan pelanggan, kinerja layanan logistik, JNE, online shop

\footnotetext{
${ }^{1}$ Corresponding author:

Email: kindarizkiw@gmail.com
} 


\section{INTRODUCTION}

The development of online shop and maket place in Indonesia began with easiness when consumers buy the goods needed. Besides, the transaction process between the seller and the buyer becomes more effective and efficient. This makes logistics industry services competing to cooperate with online shops and market places in order to facilitate consumers. Because logistics companies are currently business partners, so then they can launch business transactions between online shops and their customers.In addition, the behavior of Indonesian people who are now an active customers of online shop makes 12th December as Commemoration date of National Online Shopping Day (HARBOLNAS). However, this has become a problem for logistic companies in Indonesia. Therefore, there are tens of millions of packages that need to be sent to online shop customers. This is beyond the ability of logistic companies in Indonesia. It occurred in China every 11th of November (Yu et al. 2015).

It causes delays in the arrival of goods to consumers. Yet, complaints about delays are directed to the online shop and not to the logistics company. Thus, the online shop must bear the burden of customer complaints (Zhou, 2013). Therefore, in choosing a logistics company for an online shop, maintain customer satisfaction is very important (Yu et al. 2015). Online shop is as a product seller and evaluated directly by the end customer, but with a partner relationship between an online shop and a logistics company, the final customer satisfaction level becomes a combination between an online shop and a logistics company (Yu et al. 2015).

According to Bouzaabia et al. (2013), evaluating logistics capabilities in a company is by increasing the value of products or services as follow; tracking and tracking information, the accuracy of the product received, the accuracy of the recipient's location, the speed of arrival, the condition or condition of the product, and the appropriate price (Mentzer et al. 2001; Bienstock et al. 2008).

Therefore, an effort conducted by the logistic company is by improving logistics services. These services are important for online shops registered at a market place. Based on SERVQUAL theory, logistics services need to pay attention to several aspects such as; tangibles, reliability, responsiveness, assurance and empathy (Akter et al. 2010; DeLone and McLean, 2003).
For cases in Indonesia, there are some active logistic services in helping the smoothness of business transactions between online shops to consumers. There are companies that have higher interests than other logistics ones, such as JNE and J\&T Express. JNE is a logistics company that was founded in 1990 and has 6,000 locations spread throughout Indonesia. It makes JNE a logistics company in Indonesia that is easily accessed by the people of Indonesia (www.jne.co.id). The success of JNE can inspire other businesses in the same field by using a name that is almost similar to JNE's name such as J\&T (Prasetyo, 2017).

J\&T Express was founded in 2015. it is obvious that J\&T Express is a new company. However, based on the ratings from google trends as shown in Figure 1 below, it shows that J\&T Express has become JNE's competitor for the past one year and can be superior to other logistics companies. Thus, JNE and J\&T compete especially in the services quality provided by each company to online shop partners to make online shops as their customers are satisfied.

Based on Spreng and Mackoy (1996), customer satisfaction and service quality play role to compare between service performance and predetermined standards (Kar, 2016). Besides, customer satisfaction is a feeling of pleasure and disappointment of someone, that arises after comparing the performance and expected product results (Kotler and Keller, 2012).

Provided service quality will be measured by using Importance Performance Analysis (IPA) and providing information on service factors which according to customers greatly affect their loyalty and satisfaction. The aim of this research is comparing the performance of logistics companies between JNE and J\&T Express using the IPA method as a comparison analysis too.

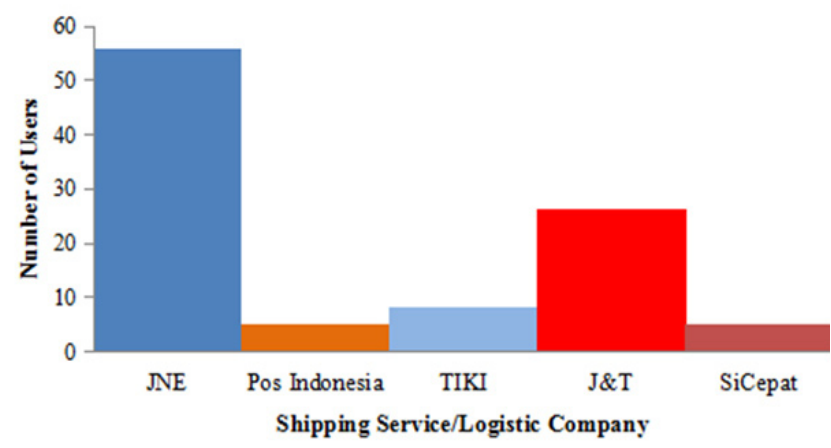

Figure 1. The average of shipping service users in 2018-2019 (Google Trends, 2019) 


\section{METHODS}

Data used in this research were primary data. Primary data were obtained from online shops that sell fashion needs because based on Figure 2, the most frequently purchased items are fashion products. However, the focus of this research was fashion online shop for women such as; veil; shirt; robe; pants; skirt; shoes and bags that register their online shop in a market place. The research was conducted with the method of data collection by distributing questionnaires to be filled directly by the owner of the relevant online shop. Respondents will be given a questionnaire directly and returned at the same time.

There were 150 respondents in this research. Sampling used the formula of Ferdinand (2005) which multiplies indicators with numbers 5-10 (Fransisca and Sugiyono 2014). The number of respondents was expected to present online shop satisfaction with the services provided by JNE and J\&T Express.

While the sampling technique was carried out intentionally (purposive sampling). Respondents would give their ratings on the numbers that corresponded to the perceived experience with the criteria score of $1=$ very dissatisfied, $2=$ dissatisfied, $3=$ less satisfied, $4=$ quite satisfied, $5=$ satisfied, and $6=$ very satisfied.

Analysis in this research used T-test, and Importance Performance Analysis (IPA) methods. T-tests was used to compare the satisfaction with the services provided by JNE and J\&T Express. The IPA method was used to provide information related to service factors which according to customers greatly affect their loyalty and satisfaction, and service factors which according to customers needed to be improved due to an unsatisfactory condition (Admin 2012).

\section{RESULTS}

\section{The Distribution of Women Fashion Industry Online Shop}

The result of the research obtained that online shops are currently spread in some regions. From Figure 3, Most online shops are in Jabodetabek area of 58\% because the most active online shoppers ae in that area. Therefore, many online shops are currently based in
Jabodetabek area, $24 \%$ in the Bandung area and $18 \%$ in other cities in Indonesia.

All respondent explains that they are registered in the market place services available in Indonesia because it facilitates their consumers in finding the items needed and make it easy for online shops to control every sale and purchase transaction. Online shops also use logistics companies of JNE and J\&T Express as their partners in sending their products to consumers.

There are some reasons that onlie shops use JNE and J\&T Express. Based on Figure 4, 22\% online shops state that the company provides fast delivery times to consumers, then $18 \%$ states that the company has a cheap price, $17 \%$ states that the tracking and tracing information provided is accurate, of $16 \%$ due to neat and safe pacing, $15 \%$ and $12 \%$ online shops like the respond and company responsibility for complaints received.

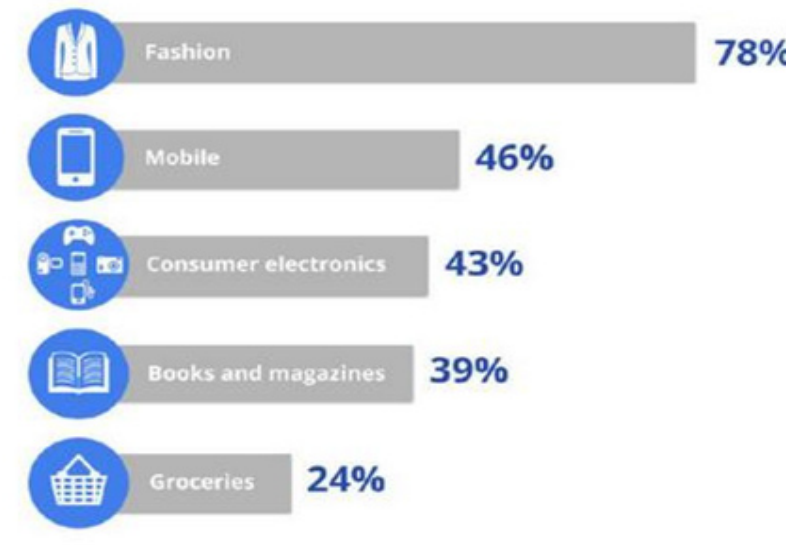

Figure 2. Ranking of items purchased in many online shops

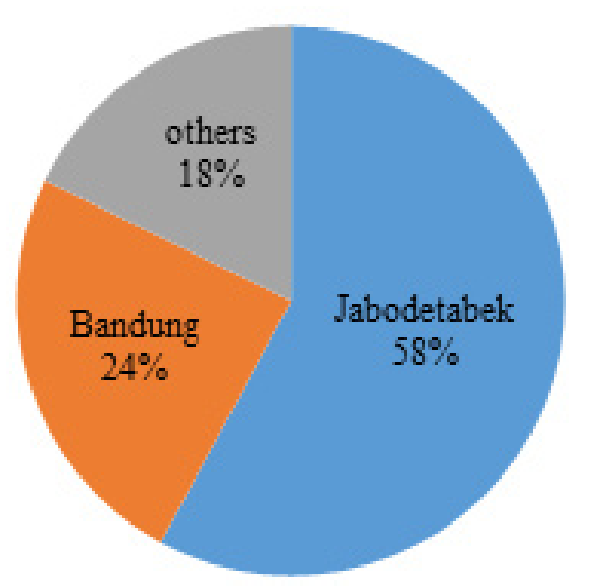

Figure 3. Area of online shop respondent 


\section{Comparison of the JNE and J\&T Express Performance Based on Customer Perception}

Based on the results of the T-test and diagram radar of online shop satisfaction, both the JNE and J\&T Express companies show results that are not much different. The results of the comparison can be seen in Table 1 and Figure 5. Of the 15 service attributes provided, there are 4 attributes that have significant differences, while the other attributes have significant similarities. All attributes that have significant differences are related to how JNE company has an advantage in maintaining the condition of goods properly and in accordance with the rates.

\section{Analysis of the JNE Logistics Company Performance}

Importance Performance Analysis (IPA) aims to provide information related to service factors that according to customers greatly influence their loyalty and satisfaction, and service factors that according to customers need to be improved due to an unsatisfactory condition (Admin, 2012). Based on the results of the study on the respondents towards the JNE company, it can be classified into four quadrants as presented in Figure 6. The quadrant analysis shows an average value of 4.76 for the level of performance and 5.14 for the level of importance, with explanations as follows.

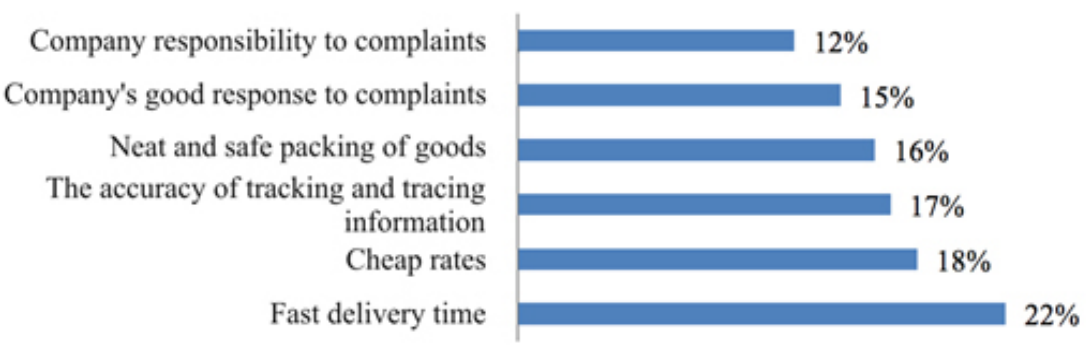

Figure 4. Online shop criteria in choosing the JNE and J\&T Express

Table 1. The results of T-Test of the JNE and J\&T Express Services

\begin{tabular}{llccc} 
& & \multicolumn{2}{c}{ Mean } & \multirow{2}{*}{ Indicator } \\
\cline { 3 - 4 } & & JNE & $\begin{array}{c}\text { J\&T } \\
\text { Express }\end{array}$ & (2-Tailed) \\
\hline 1 & The condition of goods as they are received by the customers & 5.16 & 4.86 & $0.004^{* *}$ \\
2 & The rate quality and the services obtained & 4.90 & 4.67 & $0.054^{*}$ \\
3 & The accuracy of tracking and tracing information provided & 4.79 & 4.62 & 0.163 \\
4 & Consistency of accuracy in finding the destination address & 4.97 & 4.88 & 0.435 \\
5 & Consistency of delivery time & 4.97 & 4.79 & 0.115 \\
6 & Company's responsiveness to tracking and tracing information errors & 4.72 & 4.61 & 0.334 \\
7 & Responsiveness to damaged goods & 4.58 & 4.41 & 0.185 \\
8 & Responsiveness to lost goods & 4.55 & 4.36 & 0.140 \\
9 & Guarantees for tracking and tracing misinformation errors & 4.36 & 4.40 & 0.770 \\
10 & Guarantees for destination address errors & 4.69 & 4.50 & 0.122 \\
11 & Guarantees for damaged goods & 4.53 & 4.30 & $0.076^{*}$ \\
12 & Guarantees for lost goods & 4.49 & 4.30 & 0.176 \\
13 & Company's mode of communication to its customers & 4.71 & 4.55 & 0.204 \\
14 & Company's consistency in maintaining goods properly & 4.87 & 4.64 & $0.050^{*}$ \\
15 & Company's way in responding to customer complaints & 4.71 & 4.59 & 0.325 \\
\hline
\end{tabular}

$* *$ significant at $5 \% *$ significant at $10 \%$ 


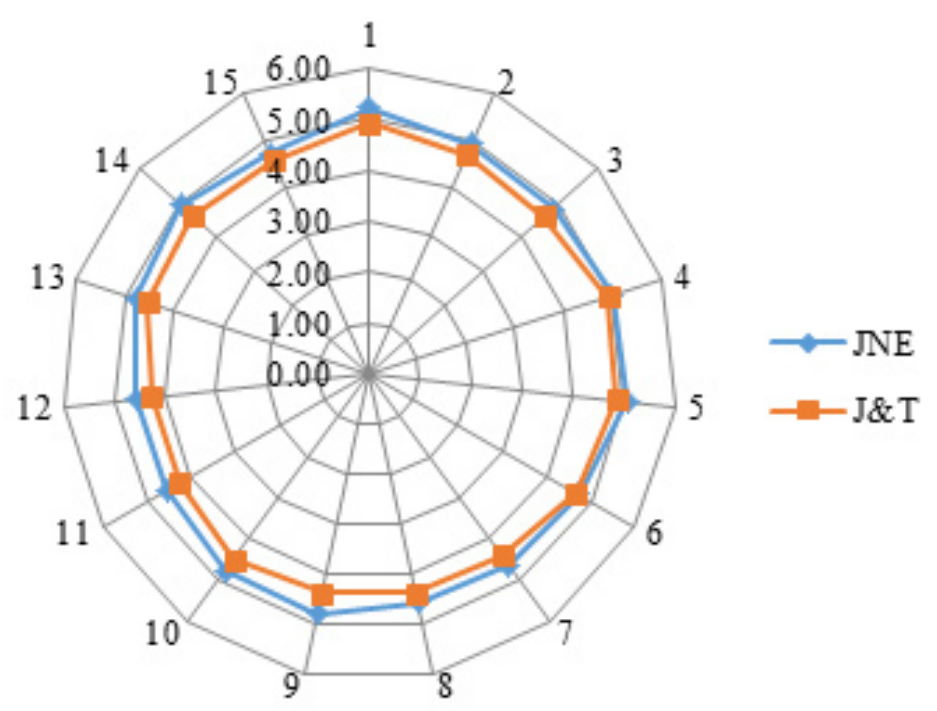

Figure 5. Comparison of the JNE and J\&T Express Performance

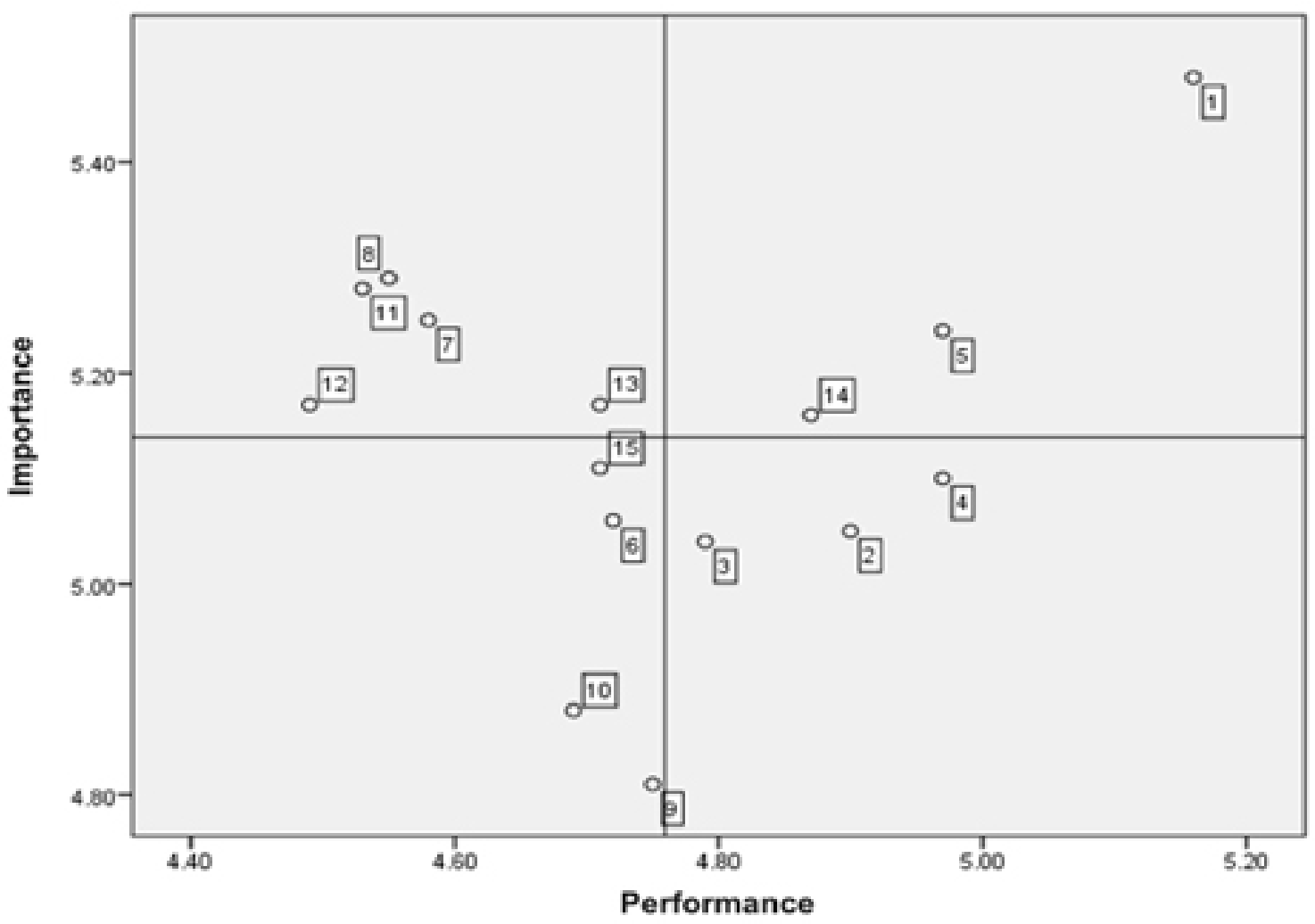

Figure 6. The results of importance performance analysis of the JNE Company

\section{Quadrant I (Top Priority)}

This quadrant shows the service attributes with a high level of importance, but the level of performance provided by JNE is considered low by the online shops. Therefore, the attributes included in this quadrant are required to be improved by making improvements by the
JNE company. Based on the results of the analysis, the attributes included in this quadrant are responsiveness to damaged goods, responsiveness to lost goods, guarantees for damaged goods, guarantees for lost goods and the company's mode of communication to its customers. 


\section{Quadrant II (Maintain Performance)}

This quadrant shows the service attributes with a high level of importance and a high level of performance. The attributes included in this quadrant can be maintained and must be managed well because they have advantages. Based on the results of the analysis, the attributes included in this quadrant are the condition of goods as they are received by the customers, consistency of delivery time to the customers, and the company's consistency in maintaining goods properly.

\section{Quadrant III (Low Priority)}

This quadrant shows the service attributes with a low level of importance and low level of performance. The attributes included in this quadrant still need to be considered, observed and controlled periodically because the level of importance can change. Based on the results of the analysis, the attributes included in this quadrant are the company's responsiveness to tracking and tracing information errors, guarantees for tracking and tracing misinformation errors, guarantees for destination address errors and company's way in responding to customer complaints.

\section{Quadrant IV (Excessive)}

This quadrant shows the service attributes with a low level of importance, but with a high level of performance so that they are considered too excessive by the customers. Based on the results of the analysis, the attributes included in this quadrant are the rate quality and the services obtained, the accuracy of tracking and tracing information provided and consistency of accuracy in finding the destination address.

\section{Analysis of the J\&T Express Logistics Company Performance}

Similar to the IPA analysis of the JNE company, J\&T Express is a logistics company that is widely used by online shops today and J\&T Express is a new company that has become a business competitor for the JNE in this past year. Based on the results of the study on the respondents towards the J\&T Express company, it can be classified into four quadrants as presented in Figure 7. The quadrant analysis shows an average value of 4.76 for the level of performance and 5.14 for the level of importance with an explanation as follows.

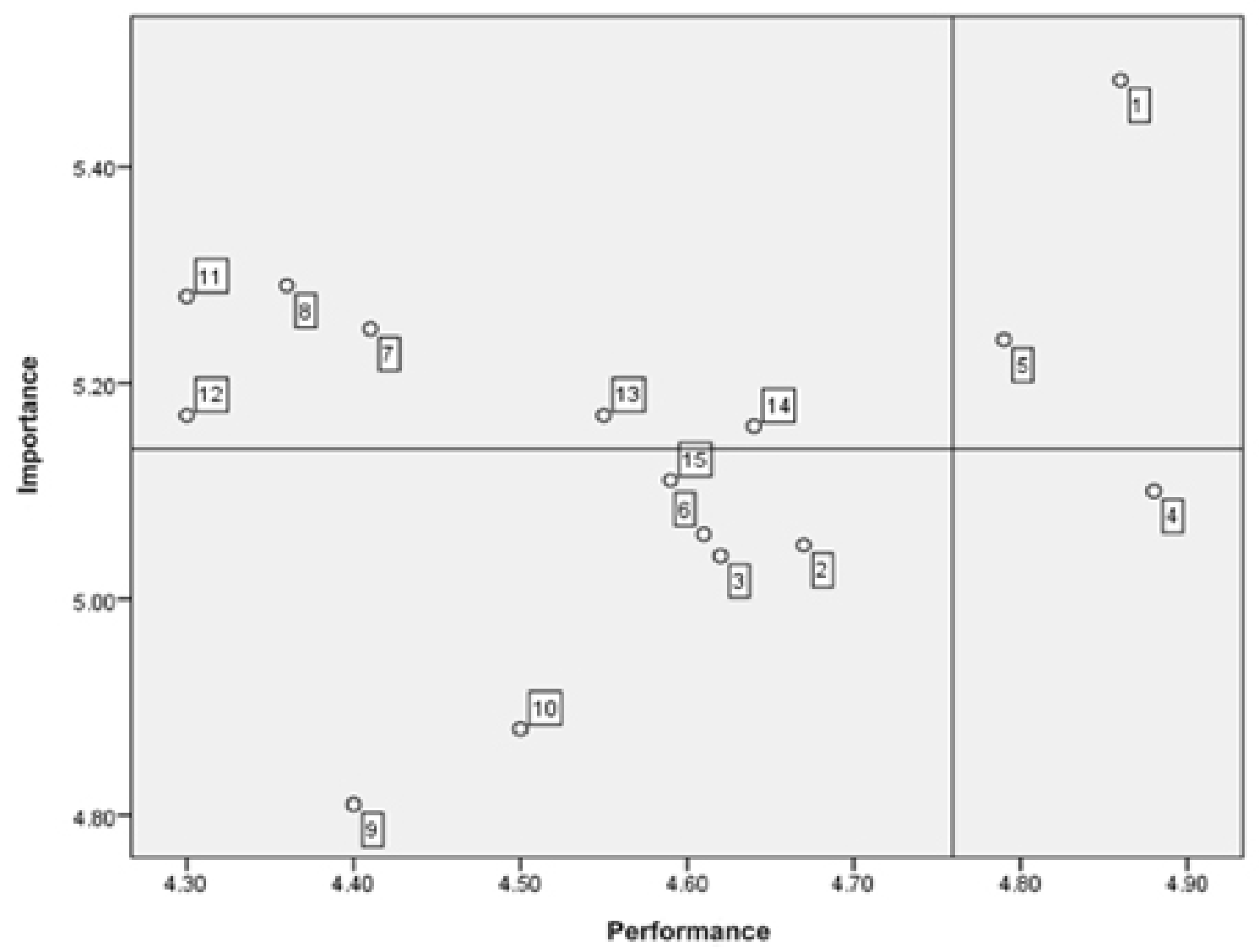

Figure 7. The results of importance performance analysis of the J\&T Express Company 


\section{Quadrant I (Top Priority)}

In this quadrant, several of the service attributes provided by the J\&T Express are required to be evaluated compared to the JNE company. Based on the results of the analysis, the attributes included in this quadrant are responsiveness to damaged goods, responsiveness to lost goods, guarantees for damaged goods, guarantees for lost goods, company's mode of communication to its customers and company's consistency in maintaining goods properly.

\section{Quadrant II (Maintain Performance)}

In this quadrant, according to the respondents, there are two service attributes provided by the J\&T Express that are the same to the JNE. It is because based on the results of the analysis, the service attributes included in this quadrant are the condition of goods as they are received by the customers and consistency of delivery time to the customers.

\section{Quadrant III (Low Priority)}

In this quadrant, there are two service attributes that have similarities with the services provided by the JNE. Therefore, based on the results of analysis obtained, the service attributes included in this quadrant are the rate quality and the services obtained, the accuracy of tracking and tracing information provided, company's responsiveness to tracking and tracing information error, guarantees for tracking and tracing misinformation errors, guarantees for destination address errors and company's way in responding to customer complaints.

\section{Quadrant IV (Excessive)}

In this quadrant, according to the respondents, the service attributes of the J\&T Express differ greatly from those of the JNE. According to the respondents, there are several service attributes provided by the J\&T Express which are slightly excessive compared to the service attributes provided by the JNE. Based on the results of the analysis, the attribute included in this quadrant is the consistency of accuracy in finding the destination address.

The results of the analysis using the IPA method and comparison between the JNE and J\&T Express logistics companies are as follows:

1. Both the JNE and J\&T Express logistics companies need to review the services of responsiveness for lost and damaged goods. It is because the final customer will give complaints to the online shop. This can lead to poor assessment and reduce the trust of the next consumers. It is because one of the aspects consumers pay attention to in buying an online shop listed at the market place is checking the reviews given by other customers. However, the error in lost or damaged goods is not the fault of the online shop, but rather from the logistics company itself. Thereby, it is necessary to pay attention to each stage of the delivery process. It is expected that logistics companies can provide a clear response when there are damaged or lost goods.

2. Both the JNE and J\&T Express companies need to review again the services of guarantees for lost and damaged goods. Referring to the previous point, in fact, there were several cases in which the companies did not provide guarantees for damaged or lost goods at the time of delivery to the final customer. This resulted in concern for the online shops for goods that will be sent to their customers. According to the online shops, although there is a factor in rate and fast delivery to customers with the choice of the JNE and J\&T Express, if it is not supported by guarantees for damaged or lost goods, the online shops as the seller of the goods will experience the impact, which is the loss.

3. Both the JNE and J\&T Express companies need to improve the company's mode of communication to its customers. The communication is intended to establish cooperation with online shops as their current partners. Moreover, different from the JNE, the J\&T Express company needs to improve its service in responding to customer complaints. These complaints from the final customers that should be given to the logistics company but given to the online shop must be assisted and they have to respond to these complaints.

\section{Managerial Implications}

The JNE and J\&T Express companies must monitor the performance of the packaging process and also the couriers who deliver the goods. For example, the quality of employees who will be employed in the packaging process should be workers who are thorough and neat in their work, while employees in the delivery process must be employees who are able to drive well on twowheeled vehicles or four-wheeled vehicles, and have the appropriate educational background. This is to reduce the occurrence of damage in the delivery process. 
In selecting field employees, both the JNE and J\&T Express should consider the age factor, in which the younger the employee's age, the greater the productivity in working compared to the older age. Thus, the intensity of each field worker will be more frequent and they will be able to reach more remote areas. In addition, paying attention to the sex of field workers is also important, with more preference to select male field employees. Although the packaging process requires female workers, the employment of male workers will make the work faster, more precise and in accordance with the time that has been promised by the JNE or J\&T Express companies.

Furthermore, JNE and J\&T Express companies provide clear agreements regarding guarantees for damaged and lost goods. The guarantee is like a form of statement of compensation for the goods sent by the logistic company in accordance with the damage goods during the shipping process. The aim is to ease the loss that will be borne by online shop.

For management of both companies, JNE or J\&T Express should gives more convenience to their partner, which are the online shops. So far, the largest revenue of the logistics companies is from the shipment of goods from online shops, in which the increase was up to $30-40 \%$ over the past year. Consequently, the service attribute of communication between the company and the online shop needs to be considered to establish mutually beneficial cooperation both for the logistics companies and the online shops.

\section{CONCLUSIONS AND RECOMMENDATIONS}

\section{Conclusions}

The result of this study the level of importance required by online shop owner in choosing a logistics service company are to have a good responsiveness to damaged and lost goods, can provide clear guarantees for damaged and lost goods, can make good communication with the consumers, the company's consistency in maintaining goods properly, and the consistency of delivery time to the consumers.

According to the online shops, both the JNE and J\&T Express companies have a lack of responsiveness and guarantees given by the company for lost and damaged goods and the company's mode of communication to its customers. Although the two companies have the same consistency in maintaining the goods properly, there were some cases in which the goods were not in a good condition as they were received by the final consumers, so the final consumers made complaints to the relevant online shop.

The impact is that some online shops obtain a bad rating from the results of consumer reviews listed in the market place. This will also influence the company's mode of communication with online shops to maintain cooperation between the two. The conclusion that quality of JNE is better compared to J\&T Express, because J\&T Express still needs to improve the quality of service, especially in maintaining goods properly.

\section{Recommendations}

This study discusses strategies to improve the performance of both companies, JNE and J\&T Express with online shop owner respondents of women's fashion. Hopefully, further research will analyze how the online shop owner's assessment in the other segment will provide a comparison of the interest and satisfaction of logistics services provided by JNE, J\&T Express or another logistic company.

\section{REFERENCES}

Admin. 2012. Importance Performance Analysis (IPA). Ensiklopedia. Usulan Perbaikan Layanan Diklat Teknik Pusdiklat Mineral dan Batu Bara dengan Dimensi Student Statification Inventory (SSI) dan Metode Lean Sigma.

Akter S, D’Ambra J, Ray P. 2010. User Perceived Services Quality of Health Services in Developing Countries. In the Proceedings of the Eighteen European Conference on Conference on Information Systems, Pretoria, South Africa.

Bienstock CC, Royne MB, SherrellD, Stafford TF. 2008. An expanded model of logistics service quality: incorporating logistics information technology. International Journal of Production Economics 113(1): 5-22. https://doi.org/10.1016/j. ijpe.2007.03.023.

Bouzaabia R, Bouzaabia O, Capatina, Alexandru. 2013. Retail logistics service quality: a cross cultural survey on customer perceptions. International Journal of Retail \& Distribution Management 41(8): 627 - 647. https://doi.org/10.1108/ 
IJRDM-02-2012-0012.

DeLone WH, McLean ER. 2003. The DeLone and McLean model of information systems success: a ten-year update. Journal of Management Information Systems 19(4): 9-30.https://doi.org $/ 10.1080 / 07421222.2003 .11045748$.

Fransisca H, Sgiyono. 2014. Perspektif konsumen terhadap retail mix di ayam bakar primarasa Ahmad Yani Surabaya. Jurnal Manajemen Pemasaran Petra 2(1): 1-9.

Kar B. 2016. Service quality and servqual model: a reappraisal. Amity Journal of Operations Management 1(2): 52-64.

Kotler P, Keller KL. 2012. Marketing Management. 14th edition. US: Prentice Hall.
Mentzer JT, Flint DJ, Hult GTM. 2001. Logistics service quality as a segment customized process. Journal of Marketing Channels 65(4): 82-104. https://doi.org/10.1509/jmkg.65.4.82.18390.

Prasetyo FP. 2017. Analisis perbandingan service quality antara jne dan $\mathrm{j} \&$ t express. Jurnal Strategi Pemasaran 4(2):1-8.

Yu J, Subramanian N, Ning K, Edward D. 2015. Product delivery service provider selection and customer satisfaction in the era of internet of thing: a chinese e-retailers perspective. International Journal of Production Economics 159: 104-116. https://doi.org/10.1016/j.ijpe.2014.09.031.

Zhou S. 2013. Logistics bottle neck of online retail industry in China. Journal of Supply Chain and Operations Management 11(2): 1-11. 